Kornelia Kończal

\title{
LES LIEUX DE MÉMOIRE/REALMS OF MEMORY: THE UNPARALLELED CAREER OF A RESEARCH CONCEPT ${ }^{*}$
}

The French historian Pierre Nora, originator of Les lieux de mémoire (1984-92), a seven-volume history of France, has expressed a deep doubt as to the potential of applying his method of historical research of memory to the past of other nations. Having completed his long-term project, he nonetheless adjusted his conviction regarding the 'exclusiveness' of the lieux de mémoire to France:

What began as an empirical, experimental, almost playful attempt to track down lieux de mémoire would thus open up infinitely more exciting new vistas: a notion improvised for the needs of the moment would then become a category in terms of which contemporary history could be made intelligible, or perhaps even more than a category, a 'concept' - a thing quite rare in history. ${ }^{1}$

The following years confirmed Nora's intuition: in the course of almost thirty years that have passed since the first volume, on the symbolic topography of France, was published, innumerable works appeared using the category of 'lieux de mémoire', with respect to a national, regional, as well as European history. Due to an enormous number of monographs, collective volumes and articles researching into realms of memory, in a more or less convincing manner, it is impossible to

* This article is a revised version of 'Pierre Noras folgenreiches Konzept von les lieux de mémoire und seine Re-Interpretationen. Eine vergleichende Analyse', Geschichte in Wissenschaft und Unterricht, 1-2 (2011), 17-36.

${ }^{1}$ Pierre Nora, 'Preface', in idem (ed.), Realms of Memory: Rethinking the French Past, trans. Arthur Goldhammer, ed. Lawrence D. Kritzman, 3 vols. (New York, 1996-8), i: Conflicts and Divisions, XVIII. 
present the career of Nora's concept in an exhaustive fashion. Hence, the following remarks attempt at providing a comparative analysis of the research perspective developed by the French historian in the 1980s, with its Italian, German, Austrian, Dutch, Luxembourgian, Russian, Belgian, and Swiss reinterpretations.

\section{II \\ FRANCE (1984-1992)}

Setting history against memory was for Nora the starting point for an afterthought on an option alternative against the thitherto-prevalent forms of national historiography. The French historian based upon this opposition his article from 1978, reminding in various respects a manifesto, published in the lexicon La nouvelle histoire. ${ }^{2}$ Six years later, Nora made the message of his text even more precise in the introduction to volume 1 of Les lieux de mémoire:

Memory and history, far from being synonymous, appear ... to be in fundamental opposition. Memory is life, borne by living societies founded in its name. It remains in permanent evolution, open to the dialectic of remembering and forgetting, unconscious of its successive deformations, vulnerable to manipulation and appropriation, susceptible to being long dormant and periodically revived. History, on the other hand, is the reconstruction, always problematic and incomplete, of what is no longer. Memory is a perpetually actual phenomenon, a bond tying us to the eternal present; history is a representation of the past. ${ }^{3}$

Making the opposition of history and memory his starting point, Nora claimed that the French national memory has been fading since the 1960s. He situated this 'time of quandaries and loss of trust' in the context of thorough transformations of the French society, aroused and accelerated by processes such as globalisation, democ-

2 Pierre Nora, 'Mémoire collective', in Jacques Le Goff, Roger Chartier and Jacques Revel (eds.), La nouvelle histoire (Paris, 1978), 398-401.

${ }^{3}$ Pierre Nora, 'Entre mémoire et histoire', in idem (ed.), Les lieux de mémoire, 7 vols. (Paris, 1984-92, 2nd edn 1997), i, 23-42; here, 24-5; English trans. Marc Roudebush: 'Between Memory and History: Les Lieux de Mémoire', Representations, 26: Memory and Counter-Memory (special issue) (1989), 7-25; here, 8.

${ }^{4}$ Tony Judt, 'A la recherche du temps perdu. Review of Pierre Nora, Realism of Memory: The Construction of the French Past', New York Review of Books, 3 Dec. 1998, 51-8; here, 52. 
ratisation, popularisation, medialisation, decolonisation, emancipation, and fragmentation. The end of grand narratives and the birth of new forms of history perception have led to milieux de mémoire being replaced by lieux de mémoire.$^{5}$ The incentive for Nora to deal with memory was, thus, the sense of its being lost. ${ }^{6}$

In the programme introduction to volume 1 , certain attempts at defining the analytical category created by Nora can be found:

These lieux de mémoire are fundamentally remains. ... They make their appearance. ... Lieux de mémoire originate in the sense that there is no spontaneous memory, that we must deliberately create archives, maintain anniversaries, organize celebrations, pronounce eulogies, and notarize bills because such activities no longer occur naturally. ${ }^{7}$

In Nora's concept, a lieu de mémoire is 'any of material or immaterial meaning that has been made part of a community's memorial legacy through the will of people or action of time ...'; $;$ elsewhere, he says of 'points of crystallisation of our national heritage'. ${ }^{9}$ In spite of a topographic dimension suggested by the notion, ${ }^{10}$ a lieu de mémoire may designate a real site or venue, a real or mythic figure, events and occurrences, songs, symbols, literary texts, festivities, rituals, institutions, and so on. Among almost 130 lieux de mémoire, there are phenomena as various as the 14th of July, the Eiffel Tower, Joan of Arc, the Larousse dictionary, La Marseillaise, Proust's À la recherche du temps perdu, Reims, Verdun, or, wine.

Nora's project of a new conceptualisation of the history of France consisted in a general, thematic, chronological, and linear story being replaced by an in-depth analysis of 'realms' where the memory of the French nation is condensed, embodied, and

${ }^{5}$ Nora, 'Entre mémoire et histoire', i, 23.

${ }^{6}$ Constance Carcenac-Lecomte, 'Auf den Spuren des kollektiven Gedächtnis. Gemeinsamkeiten und Unterschiede zwischen den 'Lieux de memoire' und den 'Deutschen Erinnerungsorten'”, in Jan Motte and Rainer Ohliger (eds.), Geschichte und Gedächtnis in der Einwanderungsgesellschaft. Migration zwischen historischer Rekonstruktion und Erinnerungspolitik (Essen, 2004), 121-30.

${ }^{7}$ Nora, 'Between Memory', 12.

${ }^{8} \mathrm{Idem}$, 'Comment écrire l'histoire de France', in idem (ed.), Les lieux de mémoire, ii, 2219-36; here, 2226.

${ }^{9}$ Nora, 'Das Abenteuer', 83.

${ }^{10}$ Frances A. Yates, The Art of Memory (London, 1966). 
crystallised. ${ }^{11}$ This novel and, at the time it was proposed, rather experimental reading of the history did not come across a common understanding at once: in 1978-81, Pierre Nora conducted a seminar at the Paris École des Hautes Études en Sciences Sociales (EHESS), in the course of which he was 'testing' that emerging form of historiography. Mona Ozouf recollected years after a consternation appearing among the audience, and incomprehension Nora's idea faced. ${ }^{12}$

The original objective for the French historian was to carry out a kind of stocktaking of the national memorial legacy and heritage, in order to protect it from oblivion. The lieux de mémoire selected by Nora were initially related to the Third Republic period only. With time, however, the project was significantly expanded, eventually extending to a global depiction of the symbolic topography of France: a total of seven volumes have ultimately been produced, in lieu of the planned four. Rather easy to guess, the key category - lieu de mémoire - was reformulated, which was most clearly reflected in the editor's commentaries opening or closing each of the volumes.

According to Nora, researchers cognising the mechanisms of emergence, circulation, and functioning of lieux de mémoire, they have to make use of a deconstruction technique:

This process of deciphering lies at the core of the venture.... On the one hand, there is an object constructed as a symbol; on the other, it is deconstructed. In the former case, mute objects are given voice, life is inspired and meaning added to what has hitherto been lifeless or meaningless. In the latter, the contrary is true: the intimacy of an overly vivid obviousness calls for being repealed, and the original strangeness unveiled of what time has offered us as heritage. ${ }^{13}$

Based on such 'constructivist approach', it is impossible, though, to derive any specific guidelines for a researcher to follow. It would be worthwhile, instead, to refer to two, of the total of six, of Nora's analyses of lieux de mémoire. In his essay on generation as a lieu de mémoire, ${ }^{14}$ Nora analysed the differences between the generational

11 Pierre Nora, 'Preface', in idem (ed.), Realms of Memory, i, XVI.

${ }^{12}$ Mona Ozouf, 'Le passé recomposé. Propos recueillis par Jean-François Chanet', Magazine littéraire, 307 (1993), 22-5.

${ }^{13}$ Pierre Nora, 'Présentation', in idem (ed.), Le lieux de mémoire, iii, 3873-6; here, 3874.

${ }^{14}$ Idem, 'La génération', in idem (ed.), Les lieux de mémoire, ii, 2975-3015. 
experience of 1789 and the one of 1968; with regard to the May 1968 events, he pointed out two research perspectives, analysing the memory of 1968 as post-history and recollections of the 1968 generation. His article on the Gaullists and communists ${ }^{15}$ opens up a comparative perspective in the writing of a history of collective memory, displaying the extensive and flexible nature of the 'realms of memory' concept as such, as in this case subject to inquiry are milieux, rather than lieux, de mémoire. Many other articles of the sevenvolume work similarly offer no consistent discernment between lieux, media, and bearers of memory.

The methodological heterogeneity of the studies published in the collective volumes edited by Pierre Nora is to a large extent implied by the fact that their authors include more than a hundred representatives of various disciplines of the humanities. It is remarkable that Nora has successfully invited a number of renowned French historians to join the project - including Jacques Le Goff, Mona Ozouf, Jacques Revel, Marcel Gauchet, or François Furet, among others - along with scholars from Israel, Poland, Switzerland, Italy, and the U.S. As he highlighted, winning the authors over and implementation of the project was to a remarkable extent facilitated by his double affiliation: as a history professor with EHESS, and a reader with the Gallimard publishers. Added to that should be his serving as editor-in-chief of Le débat, one of the leading French political-cultural periodicals, alongside Esprit, Les Temps Modernes and Études.

Les lieux de mémoire came across very positive responses from the French press, and critical, though appreciative, opinions among historians. How extensive the reception of the seven-volume work was is testified, apart from numerous press articles and scholarly reviews, by discussions held outside historiography. Accolades and admiration were extended to the innovativeness of Nora's concept, in the first place: collective depictions of the past ranked as the subject of research; breach with a linear historiography; and, assumption of certain aspects of the history of France, so-far-omitted. The interdisciplinary character of the volumes and their thematic variety were appreciated too. A number of articles were praised for their in-depth analyses,

${ }^{15}$ Idem, 'Gaullisten und Kommunisten', trans. Ursel Schäfer, in Pierre Nora (ed.), Erinnerungsorte Frankreichs, trans. Michael Bayer et al. (Munich, 2005), 214-52. 
based upon a rich source base, good style, and their references to original, and convincing, parallels.

A sign of the project's success is no doubt the almost 100,000 copies of the work sold, its pocket edition (1997), the appearance of the phrase lieu de mémoire in Le Grand Robert - the standard dictionary of French (since 1993), election of Pierre Nora to the Académie française (2002), and translations into English, ${ }^{16}$ Bulgarian, ${ }^{17}$ German, ${ }^{18}$ Portuguese (in Brazil) ${ }^{19}$ and Russian. ${ }^{20}$ The international career of the concept and the publishing success of the book ${ }^{21}$ ought not to override the several critical weaknesses of the project.

The limitation of the project's scope to France as a national state, in a traditional meaning of the term, aroused criticism - together

${ }^{16}$ Idem, 'Between Memory and History', 7-24; idem (ed.), Realms of Memory; idem (ed.), Rethinking France, trans. Mary Trouille, ed. David P. Jordan, 4 vols. (Chicago, 2001-10). For the history of the 'export' of the publication edited by Nora to the U.S., cf. François Dosse, Pierre Nora. Homo historicus (Paris, 2011), 351-3. For the reception of the book in the U.S. (apart from the afore-quoted article by Tony Judt): Steven Englund, 'The Ghost of Nation Past', Journal of Modern History, lxiv, 2 (1992), 299-320; David A. Bell, 'Paris Blues', The New Republic, 217, 1 Sept. 1997; Christopher Todd, 'Book Reviews: French Studies Realms of Memory, vol. 1: Conflicts and Divisions', Journal of European Studies, 27, 1 (1997), 114-15; idem, 'Book Reviews: French Studies Realms of Memory, vol. 2: Traditions', ibidem, 28, 1 (1998), 191-2; idem, 'Book Reviews: French Studies Realms of Memory, vol. 3: Symbols', ibidem, 28, 4 (1998), 414-15; Tony J. Bodnar, 'Pierre Nora, National Memory, and Democracy: A Review', Journal of American History, 87, 3 (2000), 951-63; Hue-Tam Ho Tai, 'Remembered Realms: Pierre Nora and French National Memory', American Historical Review, 106, 3 (2001), 906-22; Aimée Boutin et al., 'Introduction: Memory in France', Journal of European Studies, 35, 1 (2005), 5-9; Ann Rigney, 'Plenitude, Scarcity and the Circulation of Cultural Memory', ibidem, 11-28; Ross Poole, 'Memory, History and the Claims of the Past', Memory Studies, i, 2 (2008), 149-66; esp. 159-61.

${ }^{17}$ Pierre Nora (ed.), Mesta na pamet, i: Ot republikata do naciâta, trans. Stoân Atanasov (Sofia, 2004).

${ }^{18}$ Nora, Zwischen Geschichte; Mona Ozouf, "Das Pantheon. Freiheit, Gleichheit, Brüderlichkeit”. Zwei französiche Gedächtnisorte, trans. Hans Thill (Berlin, 1996); Jacques Le Goff, Reims, Krönungsstadt, trans. Bernd Schwibs (Berlin, 1997); Nora (ed.), Erinnerungsorte Frankreichs.

${ }_{19}^{19}$ Pierre Nora, 'Entre memória e história: a problemática dos lugares', Projeto História, 10 (1993), 7-28.

${ }^{20}$ P'er Nora et al., Frantsiya-pamyat' (Sankt-Petersburg, 1999); idem, 'Pokolenie kak mesto pamyati', trans. and introduction G. Dashevski1̌, Novoe Literaturnoe Obozrenie, 30 (1998), 48-72.

${ }^{21}$ Gerd Krumeich, 'Le “Grand Nora”', Magazine littéraire, 307 (1993), 51-4; here, 52. 
with the implied preclusion of minorities and discourses situated beyond the (national) mainstream, and of civic dimension of the past. Some of the critics went as far as warning against the danger of sacralisation of the thus conceived French history.

Many reviewers assumed a critical attitude toward Nora's understanding of the role of historian as a priest and soldier in one (prêtre-soldat). It was also doubted whether Nora has indeed successfully challenged the classical narratives, for, it was claimed, the seven-volume study has rather become a (yet another) monument of the French historiography, rather than a breakthrough in practising this discipline. In the reference made to the role of symbols and ideas or representations, some critics warned against the risk of 'rendering the history unreal', by detaching it from 'the reality'. No harsh language was spared with regards to the selection of lieux de mémoire: pointed out was an apparent poor justification given when taking into account certain (too-specialist) topics, as well as numerous gaps (Bonaparteism, immigration, colonisation). In reference to individual articles, (too-) far-fetched simplifications were criticised, along with a frequent uncritical approach toward the object of exploration. Lastly, the use and application of the notion lieu de mémoire as a catch-all, without its meaning being made sufficiently precise, has been emphasised.

Nora's utterances are indeed abundant with associations, allegories and metaphors, and so it is hard to derive from them a clear and precise definition of this key category. His attempts at defining lieux de mémoire have been phenomenological, rather than analytical. Lack of a definitional and methodological clarity may have led to the aforementioned discord between what was assumed and what has been delivered: a number of the articles have departed from the guidelines originally set by Nora.

Remarkably, the intense interest in the Nora's work among journalists and scholars does not call into question Etienne François's assessment of an 'imagined Nora' (le Nora imaginaire): in France as well as outside it,

a contrast has been clear between an appreciable recognisability of Pierre Nora and his lieux de mémoire concept, and, the insufficient, not to say very limited and distorted, at times, knowledge of his work as such. ${ }^{22}$

${ }^{22}$ Etienne François, 'Pierre Nora und die Lieux de mémoire', in Nora (ed.), Erinnerungsorte Frankreichs, 7-14; here, 8. 
The most frequent reasons for the misunderstandings occurring are twofold: first, the dynamism characterising Les lieux de mémoire tends to be ignored; second, Nora's concept tends to be approached as a measure of all things, without taking into account its 'development potential' and its real creative reinterpretations it has been subject to in other countries and research traditions.

Ignoring the fact that Les lieux de mémoire was being written as a work-in-progress prevents one from seeing two transformations: the already-mentioned conversion of the history of Third Republic into a symbolic topography of the French history; and, the passage from a narrow into a broader concept of lieu de mémoire. Whereas the former focused on the lieu, that is, norm- and memory-building institutions, the extensive concept emphasised the mémoire, thus significantly increasing the thematic scope of research.

As far as the dynamism and development of Nora's concept are concerned, the context within which it emerged - that is, the culture of remembrance in the France of the 1980s - is also worth one's attention. Nora has, with time, revisited his initial, nostalgia-characterised evaluation whereby the French memory had entered a decline phase. The 'energy' of the French memory culture has outright inclined him, toward the project's conclusive phase, to propose a thesis of a 'tyranny of memory'.

To end with, the anchorage of Les lieux de mémoire in the French historiographical tradition cannot be omitted: as the project was conceptualised, Nora clearly distanced himself from a positivistic historiography, whilst at the same time opposing the identification of his concept with a 'history of mentalities' (histoire des mentalités). With time, however, he has expanded his perspective by placing his history of France in the context of the three great traditions of the national historiography: romanticism, positivism, and the Annales model. Hence, Nora's name could (possibly) be added to the three grand figures in the French historiography: Michelet, Lavisse and Braudel: 'A Lavisse is unthinkable today. The Lavisse has been replaced by the Nora - le Nora being nothing else than an encyclopaedic team of authors'. ${ }^{23}$

${ }^{23}$ Jacques le Rider, 'An Stelle einer Einleitung: Anmerkungen zu Pierre Noras Lieux de mémoire', in Moritz Csáky and Peter Stachel (eds.), Speicher des Gedächtnisses. Bibliotheken, Museen, Archive, pt. 1: Absage und Wiederherstellung von Vergan- 
III

ITALY (1996-1997)

Despite considerable popularity of the French methodology of history in Italy in the 1980s, the lieu de mémoire concept long passed almost unnoticed there. In as late as 1994, mediaevalist Girolamo Arnaldi openly regarded the application of the French method in relation to the history of Italy as impossible. ${ }^{24}$ Gilles Pécout, French historian specialising in the history of Italy, had an equally pessimistic opinion on the matter at that time. ${ }^{25}$ But he had to revise this judgment in 2006, at the latest, as he wrote an introduction to the French edition of a publication, edited by Mario Isnenghi, ${ }^{26}$ devoted to Italian luoghi della memoria. ${ }^{27}$ Although Isnenghi emphasised that the concept of Pierre Nora was his inspiration, the French historian was not amused with the Italian project; he even described it as a 'caricature'. ${ }^{28}$

Isnenghi explained that the work on I luoghi della memoria, preceded by many years of conceptualisation, was accelerated by radical transformations of the public discourse, taking place in Italy in mid-1990s and related to a loss of importance of the communist party, quite powerful thitherto, and a weakening of the national consensus based upon the ideas of Risorgimento and Resistenza. He conceived

genheit. Kompensation von Geschichtsverlust (Vienna, 2000), 15-22; here, 18. Incidentally, Pierre Nora also referred his work directly to Lavisse, stating that the trisection: La République - La Nation - Les Frances only makes sense in reference to the canonical model of Lavisse's history of France; cf. Pierre Nora, 'Le modèle des "lieux de mémoire"', in Étienne François (ed.), Lieux de mémoire/Erinnerungsorte: D’un modèle français à un projet allemand (Berlin, 1996), 13-17; here, 15. Nora himself has devoted one of his first articles to this French historian, idem, 'Ernest Lavisse, son rôle dans la formation du sentiment national', Revue historique, lxxxvi, 228 (1962), 73-106.

${ }^{24}$ Girolamo Arnaldi, 'Unité et divisions italiennes', Le débat, 78, 1 (1994), $31-41$.

${ }^{25}$ Gilles Pécout, 'Les lieux de mémoire: Le regard de l'historiographie italienne', Le Magazine littéraire, 307 (1993), 54-7.

${ }^{26}$ Mario Isnenghi (ed.), L'Italie par elle-même: Lieux de mémoire italiens de 1848 à nos jours, introduction Gilles Pécout (Paris, 2006). On French reception see Raymond Huard, 'Lieux de mémoire à l'italienne', Revue d'Histoire du XIXe siècle, 18 (1999), 132-5; Maïté Bouyssy, 'Lieux de mémoire italiens, de 1848 à nos jours', La Quinzaine littéraire, 929, 1 Sept. 2006.

${ }_{27}$ Mario Isnenghi, I luoghi della memoria, 3 vols. (Roma and Bari, 1996-7).

${ }^{28}$ Nicolas Weill, 'Démarquage sauvage des "Lieux de mémoire” en Italie', Le Monde, 3 Jan. 1997; Aldo Giovanni Ricci, 'La memoria degli italiani', Il Tempo, 14 Jan. 1997. 
I luoghi della memoria in terms of a reply to the situation: 'In Italy, a country deprived of memory, our intent is to swim against the tide, fulfil the duty of trustees of cultural values'. ${ }^{29}$ Isnenghi described himself as a 'defender of memory'. Clearly, what we deal with is a political intention.

Among the seventy-four Italian luoghi della memoria, items such as: Garibaldi, Matteotti, l'opera, la piazza, Pinocchio, il Giro d'Italia, Monte Grappa, il XX settembre or the national colours have been identified. Contrary to the French project, in whose conceptualisation and delivery Nora was supported by many professional colleagues, the Italian publication is a work of a single individual.

Isnenghi's primary interest was the processes of 'invention' of Italy and the Italians, as shown on the examples of events, people, and other historical phenomena that have become, in nineteenth and twentieth century, (national) realms of memory. The publication is focused on the period past 1848, and so encompasses the lieux de mémoire related to the occurrence of Italy as a national state. But such a depiction is questionable as it ignores regional dimensions of many Italian luoghi della memoria.

The Italian publication differs from its French 'original' in that it takes into account more broadly (non-Italian) 'Others': if Nora's perspective was limited to countrymen of foreign origin and a French self-image created with use of postcolonial displays, the Italian luoghi della memoria have also included America, the London Radio, and Germany. A complete omission of a universal (or, at least, transnational) nature of many an Italian realm of memory seems to be a serious deficit of I luoghi della memoria.

Another peculiar trait of the Italian project is the author's interpretational effort: in the conclusion of the last volume, Isnenghi takes a chance to interrelate the individual luoghi della memoria, thus creating a specific type of synthesised history of Italy of the last 150 years.

Within a dozen-or-so months of publication of I luoghi della memoria, thirty-seven reviews were published in the Italian press: mostly positive, with some critical opinions voiced - not surprisingly, having regard of the project's clearly political ambition.

${ }^{29}$ Mario Isnenghi, 'Conclusione', in idem, I luoghi, iii, 429-474; here, 432. 


\section{IV \\ GERMANY (2001)}

The idea to apply the concept of lieux de mémoire with the history of Germany was conceived at a German-French-Polish conference held in 1994 at the German Historical Institute in Warsaw. A year later, Étienne François and Hagen Schulze inaugurated at the Friedrich Meinecke Institute of the Freie Universität in Berlin a six-semester seminar on German Erinnerungsorte. During a conference organised in 1995 at the Centre Marc Bloch, Berlin, the idea of German reinterpretation of Nora's ideas was subject to a discussion attended by the French scholar in person. ${ }^{30}$ As he highlighted on the occasion,

The very fact that a French 'model' exists renders one obliged to search for a different arranging criterion - one that would draw its legitimisation from 'the Germans' attitude toward 'their' past. And this is where the problem arises: which Germans, namely? What attitude? What past? ${ }^{31}$

Étienne François pointed to six features characteristic to the German history, whose importance for conceptualisation of the project has been crucial: (i) resulting from a dominance of culture and language over the state, a total of 18 paramount categories structuring the study have been selected: from Bildung (educational formation) through to Zerfall (disintegration); (ii) the continual questioning of German identity has disposed the editors toward quitting a normative definition of the German 'us', to the benefit of an open-ended concept; hence, much attention was devoted to shared realms of memory; (iii) the incessantly discontinued continuity of the German history spoke in favour of rejection of a hierarchising narrative and prompted that the rule of associations be made the foundation; (iv) due to a belated (Helmuth Plessner) nation-building in Germany emphasis has been put on the nineteenth and twentieth centuries; (v) having regard to the changeability of the German borders and intensive contacts with

${ }^{30}$ Étienne François, 'Von der wiedererlangten Nation zur Nation wider Willen. Wie ließe sich eine Geschichte der deutschen Erinnerungsorte schreiben?', in idem, Siegrist and Vogel (eds.), Nation und Emotion, 93-107.

${ }^{31}$ Nora, 'Le modèle', 15. For more on the German 'import' of the French concept, see Tilmann Robbe, Historische Forschung und Geschichtsvermittlung. Erinnerungsorte in der deutschsprachigen Geschichtswissenschaft (Formen der Erinnerung, 39, Göttingen, 2009). 
the neighbouring societies, it was resolved that the history of their interconnectedness be more strongly taken into account, which in turn led to inviting twenty-five foreign authors to contribute. As François and Schulze emphasised,

Germany [ought] not to be described as an entity closed within its own borders, as Nora does this for France; what we thus have in mind is a Germany open toward its neighbours and Europe - not only owing to continually altered frontiers and ethnical territories but also due to the multiplicity of regions and venues where Germans and non-Germans lived together for centuries. ${ }^{32}$

Lastly, (vi) the intensity of German public debates on the past was the incentive for quitting the form of scholarly article in favour of an essay encouraging the reader to give thought and complement their reading.

The editors of the Deutsche Erinnerungsorte understand the 'realms of memory' not as a notion, in a philosophical-analytical sense, but as a metaphor:

A realm of memory may include a material as well as non-material phenomenon. ... [These are] long-lasting crystallisation points of collective memory and identity, constitutive for several generations, which, being part of social, cultural, and political customs, tend to change insofar as the ways they are perceived, absorbed, used, and transposed changed. ${ }^{33}$

121 Erinnerungsorte have eventually been selected, out of 500 considered. These included historical events and individuals, institutions, processes, slogans, festivities and rituals, geographic places, literary, musical and artistic works, individuals, sayings, symbols.

The motivation and purpose of the German project was the most evident difference, comparing to the publications conceived by Nora and Isnenghi: François and Schulze quit the diagnosing of the present not intending to save what was perishing or to tend a national memory ('Our project is neither rule-making nor pro-state'. ${ }^{34}$ ). What François and Schulze aimed at was, rather, to deliver an open concept of lieux de mémoire - but they were aware of what has affected their project's

32 Étienne François and Hagen Schulze, 'Einleitung', in iidem (eds.), Deutsche Erinnerungsorte, i (Munich, 2001), 9-24; here, 19.

${ }^{33}$ Ibidem, 17-18.

${ }^{34}$ Ibidem, 23. 
nature: the intelligentsia-related, Western and Berlin background, and a special role of the history of the French-German relations. Those particular limitations to the Deutsche Erinnerungsorte were pointed out by many reviewers, albeit the complaint that the history of everyday life and popular culture has not been considered is apparently not quite legitimate: the three volumes contain essays on, i.a., the Bundesliga, the schlager music, or allotments.

Many reviewers (2001 alone saw more than a hundred reviews published in German mass media) criticised the proposed selection of realms of memory - although, compared to the previous counterparts, François and Schulze doubtlessly defined in the clearest manner the criteria for their choice. Along with nineteenth and twentieth century, the focus has been put on 'forms of expression of collective memory' that 'have existed for some time now, in a ripe form'. It was a deliberate idea, then, to leave aside the most recent phenomena - 'the collective memory of young Germans of Turkish descent, resettlers (Spätaussiedler), war refugees, and asylum seekers' ${ }^{35}$ Some reviewers demanded that the history of the German Democratic Republic or a gender perspective be taken into consideration to a clearer degree; others grumbled that no separate articles have been dedicated to topics such as the Wehrmacht, Hitler or Third Reich.

The structure of the German publication has come across diverse opinions: some commended the originality of the 'typology' proposed by François and Schulze, while others criticised the arbitrariness with which the realms of memory have been assigned to the respective chapters. The 'order of things' conceived by François and Schulze renders the German project different from Les lieux de mémoire and I luoghi della memoria, neither of which paid much attention to such taxonomy. A strong point in the German approach is that the reader's imagination is stimulated by evoking diverse, sometimes unexpected, sequences of associations: one example being a chapter encompassing phenomena as different as the Reich, Canossa, and Nuremberg.

The success of the German publication has been evidenced not only by its several reissues and a French translation ${ }^{36}$ but also its inspiring role: the François and Schulze book has induced several

${ }^{35}$ Ibidem, 22.

${ }^{36}$ Étienne François and Hagen Schulze (eds.), Mémoires allemandes (Paris, 2007). 
other projects analysing lieux de mémoire of many German regions. ${ }^{37}$ Instances have also occurred of a practical application of interpretations of the German past through the lens of memory studies in the history didactics: in 2005 the Federal Agency for Civic Education (Bundeszentrale für Politische Bildung) has issued a collection of essays from Deutsche Erinnerungsorte; a collection of materials for teaching of German as a foreign language has been published (2007), ${ }^{38}$ a chapter in the first volume of a French-German textbook for history ${ }^{39}$ focuses on a 'memory of the Second World War', the second volume taking a similar approach toward the so-called French-German 'hereditary' enmity (Erbfeindschaft). Such focus on the didactic aspect of collective memory research has to date proved unique in Europe.

\section{$\mathrm{V}$ \\ AUSTRIA (2004-2005)}

It is rather tough for Austria ...: not a trace of a Rütli Oath, a founding myth, or a Marseillaise. Around what symbols and identity patterns does

${ }^{37}$ Carsten Fleischhauer and Guntram Turkowski (eds.), Schleswig-Holsteinische Erinnerungsorte (Stiftung Schleswig-Holstein Landesmuseum Schloss Gottorf, Heide, 2006); Kurt Bohr and Peter Winterhoff-Spurk (eds.), Erinnerungsorte - Ankerpunkte saarländischer Identität (St. Ingbert, 2007).

${ }^{38}$ Sabine Schmidt and Karin Schmidt (eds.), Erinnerungsorte - Deutsche Geschichte im DaF-Unterricht. Materialien und Kopiervorlagen mit Dokumenten-CD-ROM und CD (Berlin, 2007). Cf. a review by Uwe Koreik and Lutz Köster, Informationen Deutsch als Fremdsprache, 2/3 (2008), 335-7. For an earlier example of afterthought on pedagogical work based upon the 'site of memory' concept, see Heidi Behrens and Andreas Wagner (eds.), Deutsche Teilung, Repression und Alltagsleben. Erinnerungsorte der DDR-Geschichte. Konzepte und Angebote zum historisch-politischen Lernen (Leipzig, 2004). Meanwhile, considerations have come out on the potential of the paradigm of studies on collective memory in learning the Italian language; cf. Daniel Reimann, 'Erinnerungsorte im Fremdsprachenunterricht. Fachdidaktische Grundsatzüberlegungen und Lehrwerkanalyse am Beispiel des Italienischen', in Norbert Becker, Hannelore Martin and Susanne Zieglmeier (eds.), Vorschläge für die Praxis des Italienischunterrichts. Akten der Sektion Didaktik des Deutschen Italianistentages "Orientierungen im Raum" in Bochum, März 2006 (Munich, 2008), 108-19.

${ }^{39}$ Peter Geiss and Guillaume Le Quintrec (eds.), Histoire/Geschichte: l'Europe et le monde depuis 1945, manuel d'histoire franco-allemand. Terminales L/ES/S (Paris, 2006); iidem (eds.), Histoire/Geschichte: Europa und die Welt seit 1945, Deutsch-französisches Geschichtsbuch. Gymnasiale Oberstufe (Stuttgart and Leipzig, 2006). 
this nation unite, then, without wriggling convulsively? What can be deemed to be typically Austrian? ${ }^{40}$

This dilemma has pushed Emil Brix, Ernst Bruckmüller and Hannes Stekl, editors of a three-volume publication Memoria Austriae, ${ }^{41}$ to carry out a representative survey on 'figures of memory constitutive for the Austrian identity'. The goal of this procedure was 'to exclude myth--making based on the historical canon and stemming from the subject of research being determined by scholars themselves'. ${ }^{42}$ The survey's outcome subsequently became the basis for selection of entries: a total of forty-three articles have been written, focusing on the issues indicated by the largest numbers of the respondents. Those included, i.a.: the Danube, the Habsburg myth, Empress Maria Theresa, Wolfgang Amadeus Mozart, the St Stephen's Cathedral, the Ringstraße in Vienna, Swarovski, and the Czechs. The identified lieux de mémoire have been assigned to the following categories: People, Myths, Times (vol. 1); Buildings, Places, Regions (vol. 2); and, Entrepreneurs, Businesses, Products (vol. 3). The proposed depiction of economic questions, to which an entire volume has been dedicated, is characteristic. One might doubt, however, whether the question of what would be typically Austrian really leads to a knowledge on collective identity, rather than producing findings proving of use in the research of recognisability of brands and products.

As was the case with French counterpart, Memoria Austriae comprises texts whose central subject-matter is not the specific lieux de mémoire but entire thematic complexes (as in the articles on Sport heroes or Exponents of imitative arts in the Austrian collective memory). It is astonishing that certain themes have appeared on this occasion: the texts on Tourism, or Sites commemorating the fallen in World War II and victims of the Nazi terror are no doubt of significance for research into Austrian collective memory, but are not really realms, as much as media or bearers, of memory.

The usefulness of a survey forming the basis of the Memoria Austriae concept was one of the objects of criticism from many reviewers.

\footnotetext{
40 Wolfgang Straub, 'Schnitzel und Erinnerungsorte', Der Standard, 22 Oct. 2005.

${ }^{41}$ Emil Brix, Ernst Bruckmüller and Hannes Stekl (eds.), Memoria Austriae, 3 vols. (Vienna and Munich, 2004-5).

42 Iidem, 'Vorwort', in ibidem, i, 8.
} 
This instrument only records the present-day situation and is thus fit for researching a culture of remembrance in a given period, rather than a history of memory. The quality of replies so gained triggers doubts as well, since

the identity processes manifesting themselves in this research [comprise] an essential moment of denial [Verdrängungsleistung] ..., the most frequent replies given by the respondents with respect to lieux de mémoire ought therefore to be read as a subjective and idealised image of themselves, rather than an objective historical and social reality $\ldots . .{ }^{43}$

It was probably this characteristic of survey-based research that has caused that in the three volumes of Memoria Austriae a text of the Vienna Heldenplatz, or on the Anschluss of Austria in 1938, is missing. The way the survey' outcome has been made use of in the Austrian project accentuates the advantages of such an approach - the topicality and a social control of academic intuitions, as well as its limitations - a temporary and selective nature of the questionnaire outcome.

\section{VI \\ THE NETHERLANDS (2005-2007)}

The four-volume Plaatsen van herinnering ${ }^{44}$ was written in the context of intensive discussion on the Dutch identity in the globalisation and migration epoch. The goal of this project was not to heroise, or ridicule, or demonise, but rather to de-mythologise some Dutch plaatsen van herinnering. ${ }^{45}$ Although the initiator of the Dutch project had a different purpose than Isnenghi, Henk L. Wesseling realised that his publication bore a (potential) political dimension. He was aware it would make a contribution to the discussion on the Dutch history and identity. ${ }^{46}$

\section{${ }^{43}$ Le Rider, 'An Stelle', $20 \mathrm{f}$.}

${ }^{44}$ Wim van den Doel (ed.), Plaatsen van herinnering. Nederland in de twintigste eeuw (Amsterdam, 2005); Jan Bank and Marita Mathijsen (eds.), Plaatsen van herinnering. Nederland in de negentiende eeuw (Amsterdam, 2006); Maarten Prak (ed.), Plaatsen van herinnering. Nederland in de zeventiende en achtiende eeuw (Amsterdam, 2006); Herman Pleij and Wim Blockmans (eds.), Plaatsen van herinnering. Nederland van prehistorie tot Beeldenstorm (Amsterdam, 2007).

${ }^{45}$ Henk L. Wesseling, 'Plaatsen van herinnering: een nieuwe visie op het verleden. Algemene inleiding bij de reeks', in Pleij and Blockmans (eds.), Plaatsen van herinnering, 15-21; here, 20.

${ }^{46}$ Ibidem, 21. 
Plaatsen van herinnering is comprised of articles on 164 realms of memory, prepared by as many as 150 authors. The entries are set in a chronological and retrospective order: the first volume deals with the twentieth century; volume 2 is devoted to nineteenth century; vol. 3 - seventeenth and eighteenth centuries; the fourth covers the earlier period: from prehistoric to the Beeldenstorm of 1566. In contrast to the previous projects, the Dutch authors resolved to apply a consistently topographic approach; as a result, Anna Frank appears, for instance, not in connection with her diary but, rather unexpectedly, as part of a description of the house bearing her name in the Amsterdam Old Town.

Each of the volumes is furnished with a map in which the places under discussion are plotted. The topography of Plaatsen van herinnering is not limited to the Netherlands, or Holland, with as many as sixty-eight sites of memory located outside the country's borders; ${ }^{47}$ hence, no 'Netherlands-centrism' is the case whatsoever.

Specific to the Dutch project is the entries being focused, as already mentioned, on topography - a factor that, on the one hand, narrows down the perspective, almost precluding realms of memory having no topographic reference whilst, on the other, opening up a new presentation potential. This has been taken advantage of in a twofold way: each of the essays is illustrated with a photograph of the site in question; the Dutch National Archive (Nationaal Archief) website ${ }^{48}$ offers the user an option to use a browser to seek information on the individual realms of memory, taking into account the regional, thematic, and chronological criteria.

VII

\section{LUXEMBOURG (2007)}

A large research project was carried out in 2004-7 in Luxembourg, aimed at analysing the genealogy of representations of the Luxembourgian past and the ways of its political and social exploitation in

${ }^{47}$ Ambon, Banda Aceh, Batavia, Brussels, Jakarta, Javazee, Holland (Michigan, U.S.), Kanchanaburi, Cape Town, Linggadjati, Munich, Münster, New York, Nieuwpoort, Nova Zembla, Paramaribo, Seedorf, Srebrenica, Surinam, Waterloo, and Willemstad/Curaçao.

${ }^{48}$ Available at <http://www.nationaalarchief.nl/plaatsen> [Accessed 10 Jan. 2009]. 
nineteenth and twentieth century. 2007 saw the issue of a publication, edited by Sonja Kmec, Benoît Majerus, Michel Margue and Pit Péporté, on the Luxembourgian lieux de mémoire. ${ }^{49}$ As opposed to Pierre Nora's project, the Luxembourgian historians did not seek to save the memory of what had been gone. Their focus was, instead, the question why certain historical phenomena had occurred 'resilient' enough so their memory has outlasted till this day. Thus, 'living' Luxembourgian lieux de mémoire were subject to analysis.

Lieux de mémoire - those 'shapeless and nebulous condensations ..., owing their coherence to the functions they fulfil' ${ }^{50}$ - are understood as material or symbolic anchorages of collective memory, whose influence on the shaping of a community's identity proves essential. Among the fifty-seven entries, national (the Red Lion) and religious symbols (the Notre-Dame de Luxembourg Cathedral; pilgrimages of the Portuguese living in Luxembourg to the Our-Lady-of-Fatima sanctuary in Wiltz) appear in parallel. Other examples include national heroes (John I of Luxembourg); founding myths (Siegfried and Melusina); symbols of occupation by alien nations and resistance (the general strike of 1942); openness and Europeanness (Emile Mayrisch, Robert Schuman, Schengen); as well as 'the world we have lost' (miners; industrial landscape on the Moselle) and traditions rooted in everyday life (wine, beer, Santa Claus). Many articles have convincingly quitted a description of the 'Luxembourgian identity', following the programme declaration in the introductory remarks, to the benefit of 'identities in Luxembourg', with account taken of overlapping temporal strata and a variety of cultural transfers. The project authors cared about not losing sight of minority discourses (mainly local, regional, migrant, religious). Thereby, they identified their goal as research into the heterogeneity of the Luxembourgian cultural memory and of the processes of formation of collective identities.

Erinnerungsorte in Luxemburg differ from the above-described projects as to form: the Luxembourgian publication is targeted at

${ }^{49}$ Sonja Kmec, Benoît Majerus, Michel Margue and Pit Péporté (eds.), Lieux de mémoire au Luxembourg. Usages du passé et construction nationale/Erinnerungsorte in Luxemburg. Umgang mit der Vergangenheit und Konstruktion der Nation (Luxembourg, 2007).

${ }^{50}$ Sonja Kmec, "Lieux de mémoire" and the (de)construction of "identities "', Hémecht. Revue d'Histoire Luxembourgeoise/Zeitschrift für Luxemburger Geschichte, 58, 1 (2006), 97-105; here, 101. 
a broad public. This is the reason why illustrations accompanying the individual articles often occupy a larger space than the text. Although most of them act as arguments, rather than merely ornaments, this narrative strategy does not (always) favour an analytical profoundness of argumentation.

\section{VIII}

RUSSIA (2007- )

Four primary differences are discernible between Les sites de la mémoire russe $e^{51}$ and the aforementioned publications on realms of memory: first, the work has not been completed yet (the dates of issue of the subsequent forthcoming volumes are not determined); second, Georges Nivat, the project originator and editor of the book, is not a historian but a literary scholar (as are most of the forty-one, mostly Russian, authors of the articles); third, the book is targeted not at Russian but, primarily, Francophone readers; lastly, fourth, the leading category for Nivat is not lieu, but instead, site de mémoire, which means that, similarly to the Dutch counterpart, topography plays the primary part, the very description site de mémoire referring to the way memory operates, which is association- and network-based.

The project aims at 'reading the sometimes contradicting layers of memory, of which the Russian culture ... is composed', ${ }^{52}$ and carrying out a peculiar 'stocktaking of this memory'. ${ }^{53}$ In Nivat's understanding, site de mémoire is a 'real or imagined place' 'in which the Russian collective memory is reflected and produced'. ${ }^{54}$ The first of the three intended volumes describes sixty-three sites of memory, grouped into fourteen chapters. The prevalent sites are museums (12 in total), towns or cities (11), Orthodox churches and monasteries (8). Texts on heathen memory, Siberia, memory of Russian military-men, memory of the nobility, venues of strolls and memory, the Orthodox liturgical year, theological traditions, places of education, reading and spectacle, and Russia as seen from abroad, appear in the subsequent chapters.

${ }^{51}$ Georges Nivat (ed.), Les sites de la mémoire russe, i: Géographie de la mémoire russe (Paris, 2007).

${ }^{52}$ Idem, 'Préface: Mémoire russe, oubli russe', in ibidem, 18.

${ }^{53}$ Ibidem, 13.

${ }^{54}$ Ibidem. 
Yet, the volume's structure is not quite convincing; it actually looks like a draft version, without a consistent idea. The reader may for example ask why the Petersburg Hermitage Museum is dealt with by as many as three texts; or, why some of the chapters cover but one or two site(s) of memory.

In contrast to the Italian publication, Georges Nivat proposed no narrative and/or interpretative framework in his introductory remarks. Rather than that, this editor tries to characterise certain properties of Russian self-stereotypes and Russian culture of remembrance: hatred toward oneself; ambivalent attitude toward the nation, frustrated between rejection and affirmation; the related tension between Slavophilism and Occidentalism. In Nivat's view, the aftermath of destruction and losses weighed heavily upon the Russian memory in twentieth century; with regards to our contemporary time, the French literary scholar writes of a coexistence of antithetical identity offers, and of an 'ecumenical retrieval of all the Russian memories, without undertaking any attempt at classifying them'. ${ }^{55}$

Although literary studies as the background of Les sites de la mémoire russe have influenced the selection of the realms of memory only in the chapter on the theatre, references to literature and appreciation of its role as a memory medium have informed the publication to an extent much larger than the case was with any of the previously discussed projects.

\section{IX \\ BELGIUM (2008)}

Similarly to its Dutch counterpart, the Belgian release on lieux de mémoire focuses on a topographical dimension of collective memory. Contributions to the work entitled België. Een parcours van herinnering [Belgium. Tracing the memory], issued (in Flemish) in 2008, ${ }^{56}$ were made by over fifty, French- and Flemish-language, exponents of social sciences and humanities, plus a few journalists. Compared to the other projects, absence of authors from outside Belgium stands out.

Making a reference to the famous Michelin guide stars, historian Jo Tollebeek tries his best to persuade the readers that Belgium 'is worth

${ }^{55}$ Ibidem, 22.

${ }^{56}$ Jo Tollebeek (ed.), België, een parcours van herinnering, 2 vols. (Amsterdam, 2008). 
visiting. ${ }^{57}$ It would however be erroneous to suppose that among the sixty-six discussed topics only places triggering positive associations would be found. The Belgian plaatsen van herinnering namely include Kigali, the capital of Rwanda, where ten Belgian UN-Forces soldiers were killed in 1994; or, the 1985 disaster at the Heysel stadium where, resulting from a panic outbreak at a football match, thirty-nine people were trampled down, with more than 400 injured. Similarly to the Dutch Plaatsen van herinnering, the Belgian sites of memory include such which are located outside of the country today: apart from the article on Kigali, texts dealing with Coburg, Kinshasa (Léopoldville) and Roubaix are included. About a half of the articles refer to Flemish localities; eleven concern various locations in Brussels; one is about the German minority in Belgium; the remainder, about localities in Wallonia.

The selected entries have been ordered into five chapters: (i) sites of history (plaatsen van geschiedenis) - referring the reader, in the first place, to the nineteenth/twentieth-century nation-building process; (ii) sites of expansion (plaatsen van expansie) - related to the country's colonial past; (iii) sites of (language-related, religious, ideological, social) conflict (plaatsen van tweedracht); (iv) sites of crises (plaatsen van crisis); and, (v) sites of nostalgia (plaatsen van nostalgie). Each chapter is preceded by a concise introduction. However, they are too brief to really fulfil a contextualising role.

Whereas the Deutsche Erinnerungsorte was reproached for no interpretative framework apparently present, one of the reviewers of the Belgian publication noted the absence of an analytical framework:

A lot would be gained if the brief introductions to each of the five chapters ran more than a mere four or five pages. Interrelations could then be shown between the individual articles; similarities and differences emphasised; the specific features analysed for the various memory communities that get mixed and overlap with one another in the Belgium of today: nation, communitarianism, language, and region. In brief, an integrating or centrifugal logic of these sites could have been explained. ${ }^{58}$

${ }^{57}$ Idem, “"Vaut le voyage”. De Belgische plaatsen van herinnerung', in ibidem, i, $13-25$.

${ }^{58}$ Hubert Roland, review: België. Een parcours van herinnering, 2 vols., Cahiers d'Histoire du Temps présent/Bijdragen tot de Eigentijdse Geschiedenis, 22 (2010), 259-62; here, 261. 
Having regard to Belgium's linguistic and regional specificity, and the related tensions between the Flemish and the Wallons, in almost all the domains of life, it seems astonishing that only a single language version of the book has been made available to date.

\section{$\mathrm{X}$ \\ SWITZERLAND (2010)}

On preparing his Schweizer Erinnerungsorte (2010), Georg Kreis faced a challenge similar to that tackled by the Belgian project's authors: 'It would be fast and easy to fill a book on the Swiss lieux de mémoire with arguments proving that to have it written is impossible, should the scholarly standards be observed'. ${ }^{59}$ This Basel-based historian, the volume's only author, has nonetheless evaded the trap of a single narrative, because he has included the confessional (Einsiedeln, for instance), linguistic (e.g. Rösti) and regional (e.g. Kaiseraugst) dimension of the Swiss national memory. The book's highlights are the essays on the mediaeval battle of Marignano, Arnold Winkelried, Johann Heinrich Pestalozzi, St Gotthard, and the banking secrecy. Having been through the articles devoted to the 'typically' Swiss topics (brands, one would willingly say), such as William Tell, Heidi, St Bernard's dog, Swissair, Swatch, and Toblerone, the sense of the subtitle: From the granary of Swissness becomes quite clear.

Kreis anticipated a criticism aimed at his selection of the realms of memory, as formulated with respect to each of the above-discussed projects, by declaring upfront that:

This present breakdown of certain national realms of memory is not dogmatic but rather experimental; that is, its intent is to help to determine, on a lookout-basis, what is and what is not explainable with use of the realms-of-memory concept, popular since the late 1980s/early 1990s. The reader may see if $s$ /he finds the proposed selection convincing. ... Clearly, the selection, which tries to take into consideration the various regions of Switzerland, as well as the division into chapters, is an invention, rather than something given. ... Why twenty-six entries? This is certainly a matter of an arbitrary decision; 20, 30, or 25, or, for instance, 27 could have been the case instead. The number 26 only adds to emphasising contingency of the 'whole' thing. ${ }^{60}$

${ }^{59}$ Georg Kreis, 'Referenzpunkte der nationalen Diskurse', in idem, Schweizer Erinnerungsorte. Aus dem Speicher der Swissness (Zürich, 2010), 313-25; here, 313. ${ }^{60}$ Georg Kreis, 'Einleitung', in ibidem, 8. 
As has been the case with many other projects researching into realms of memory, the Others - immigrants are the great absent there. The factor differing Schweizer Erinnerungsorte against the aforementioned projects - most of which are multi-volume and, always, multi-author - is a specific style of the entire work, made and written by a single author. The illustration captions suffice to display Kreis's predilection for tracing paradoxical and absurd phenomena. This, in turn, makes the book a popular-science item (the Neue Zürcher Zeitung publishing house was no incidental choice); as a result, the Swiss publication reminds its Luxembourgian counterpart in this respect.

LIEUX DE MÉMOIRE: REVISITED AND REINTERPRETED

It is difficult to agree with Moritz Csáky's criticism targeted at a national 'formatting' of lieux de mémoire research. ${ }^{61}$ All the same, the Austrian historian's unambiguous and generic opinion regarding a view of lieux de mémoire as narrowed down to a national perspective ignores two aspects: first, a growing number of projects regarding regional and transnational realms of memory; second, the essential differences between the eight 'national' projects.

Certain clear differences are observable already in the way the lieux de mémoire category is approached. The lieu-mémoire relation has been defined in a variety of ways in the respective research and/or editorial endeavours: from 'realms of memory' as a broad metaphorical concept, to a focus on its strictly topographic facet. Thereby, the least common denominator for the various concepts is a strict entanglement of lieux de mémoire with collective identity.

Another difference is with respect to the motivations and purposes of the individual projects: from scientific only, through popularising, up to definitely political. The nostalgic evaluations of Nora and Isnenghi, who approach researching into lieux de mémoire in terms of a 'rescue operation', are striking - whereas François and Schulze, for that matter, definitely stress that their analysis of German Erinnerungsorte

${ }^{61}$ Moritz Csáky, 'Die Mehrdeutigkeit von Gedächtnis und Erinnerung. Ein kritischer Beitrag zur historischen Gedächtnisforschung', an article in the Webpublished Handbuch zur Geschichte und Kultur Russlands und Osteuropas, <http:// epub.ub.uni-muenchen.de/603/1/csaky-gedaechtnis.pdf $>$ [Accessed 10 Jan. 2009]. 
claims no 'pro-state' pretences whatsoever. Hence, the differences occurring in the approach to offering the reader comprehensive interpretations. Whereas Nora and Isnenghi have provided an interpretative framework, the German, Dutch and Swiss editors refrained from providing the reader with a binding construction but rather, encourage them to reflect on the matter on their own. Both strategies have come across criticism, though: the open-ended concept was charged with arbitrariness and lack of courage in proposing theses; the interpretation-framed projects were exposed to imputation of being an instance of the so-called 'Treitschke trap', i.e. prone to teleological structures.

Other differences are observable in the criteria of selection of entries, using which the relations between active and passive lieux de mémoire, and the relation between 'trivial' and 'serious' ones, were conceptualised in a dissimilar fashion. As for the selection criteria for lieux de mémoire and their representativeness, a reviewer aptly remarked as follows:

The credibility of a map is not expressed in trying to render the Earth's surface on a one-to-one basis. The same is true for the geography of sites of memory: its credibility stems from accuracy of the scale and transparency of description of the key's symbols. ${ }^{62}$

The individual projects have different chronological centre of gravity: whereas the French concept has been transformed - from studying the history of the Third Republic to a systematic symbolical topography of France, the Plaatsen van herinnering encompassed a 'whole history of the Netherlands', and the Italian, German and Luxembourgian projects focused on the nineteenth and twentieth centuries.

Differing strategies of work on conceptualisation and preparation of the individual publications are observable too (regrettably, neither Georges Nivat nor Henk L. Wesseling have revealed the behind-thescenes of the development of their respective volumes; still, the available literature help one infer what the histories of the remaining projects were). Save for the purely editorial undertakings carried out in Italy and Switzerland, university seminars (Nora, François/ Schulze), conferences (the German and Luxembourgian case), or workshops for the authors (the case of Memoria Austriae) were held,

${ }^{62}$ Rolf Petri, “"Les Lieux de mémoire” und "I luoghi della memoria”. Ein Vergleich', Quo vadis Romania? Zeitschrift für eine aktuelle Romanistik, 15-16 (2000), 77-101; here, 95. 
at which conceptual and methodological frameworks for the projects as well as their feasibility, were discussed.

In spite of all these differences, and despite the plurality of notions - lieux de mémoire, Erinnerungsorte, Gedächtnisorte, plaatsen van herinnering and sites de la mémoire implying a somewhat different shade of meaning ${ }^{63}$ - the underlying premises for all the eight books are identical: facts description, linear narrative, and political history are clearly departed from in all the projects concerned; instead, a turn is visible toward analysis of a symbolic(al) dimension of the past, collective images, notions and representations, and the forms and functions in which history might be used in meeting the current needs. All the eight projects thereby form part of a 'history of the second degree' (histoire au second degré) horizon, as marked out by Pierre Nora, which refers to

a history less interested in causes than in effects; less interested in actions remembered or even commemorated than in the traces left by those actions and in the interaction of those commemorations; less interested in events themselves than in the construction of events over the time ...; less interested in 'what actually happened' than in its perpetual reuse and misuse, its influence on successive presents; less interested in traditions than in the way in which traditions are constituted and passed on. ${ }^{64}$

At last, the question of transfer between the individual national projects is worth touching upon. The French-German case is unprecedented in this regard. Highlighted in this context should be the belle Alliance between Etienne François and Hagen Schulze', ${ }^{65}$ their collaboration with Pierre Nora during the German project's conceptualisation phase, and a German translation of selected articles from Les lieux de

${ }^{63}$ Added to the list can be: 'geheugen-boei' ('buoys of memory'), 'realms of memory', 'places of history' as well as 'miejsca pamięci' [Polish for 'realms of memory']. Wilhelm Frijhoff, 'Dieu et Orange, l'eau et les digues. La mémoire de la nation néerlandaise avant l'État', Le débat, 78, 1 (1994), 20-30; Thomas H. B. Symons (ed.), The place of history: commemorating Canada's past: proceedings of the national symposium held on the occasion of the 75th anniversary of the Historic Sites and Monuments Board of Canada/Les lieux de la mémoire: la commémoration du passé du Canada: actes du symposium national tenu à l'occasion du 75e anniversaire de la Commissiondes lieux et monuments historiques du Canada (Ottawa, 1997); Robert Traba, Historia - przestrzeń dialogu (Warszawa, 2006).

${ }^{64}$ Nora (ed.), Realms of Memory, i, XXIII f.

${ }^{65}$ Christoph Jahr, 'Deutsche Erinnerungsblätter. Ein Archiv des kollektiven Gedächtnisses', Neue Zürcher Zeitung, 11 July 2001. 
mémoire, which was followed by some German essays getting translated into French. Again, the aforementioned French-German history textbook is an illustration of the didactic potential that lies in research concept worked out within history memory studies.

In his afterword to Deutsche Erinnerungsorte, Pierre Nora considers the question about the exportation potential of his concept to be groundless:

The question whether the concept of lieux de mémoire ... is potentially applicable in relation to other national models, is irrelevant at this moment. It is pointless to pose it, since regardless of what the reply might be - it is a matter of fact that this concept has proved its usefulness in contexts other than the French one. ${ }^{66}$

The recent ten years have brought subsequent confirmations of the Nora's observation: his concept has had a use for regional history; collective memory has become a category applied in historical comparative studies; there exist certain epoch- and problem-oriented projects. For some time now, attempts have been made at applying the 'realm of memory' category to a new reading of the history of Europe.

The significance of Les lieux de mémoire can be thus summarised as follows: first, Pierre Nora has created an extensive and inspiring work on the history of French memory; second, he has elaborated a research category that has in effect produced innumerable applications in various temporal and spatial contexts, along with numerous methodological and empirical reinterpretations. Les lieux de mémoire has thus become a seminal work of our contemporary historiography. The elasticity of the definition and scope of lieux de mémoire as proposed by Nora, ought not to be perceived (only) as its disadvantage. On the contrary: in the processes of importation and adaptation of Nora's category in other countries and research traditions, this flexibility has downright occurred to be an advantage.

trans. Tristan Korecki

${ }^{66}$ Pierre Nora, 'Nachwort', trans. Reinhard Tiffert, in Deutsche Erinnerungsorte, iii, 681-6; here, 681. 